\title{
Charles Peirce and the Hispanic World
}

\author{
Jaime Nubiola ${ }^{1}$ \\ (University of Navarra, Spain) \\ inubiola@unav.es
}

A surprising fact in the historiography of $20^{\text {th }}$ century Hispanic philosophy is its almost total opacity towards the American tradition. This deep rift between the two traditions is even more striking when one realizes the almost total neglect in the Hispanic world of such an outstanding Hispanic-American thinker as George Santayana, or the real affinity between the central questions of American pragmatism and the topics and problems addressed by the most relevant Hispanic thinkers of the last century: Miguel de Unamuno, José Ortega y Gasset, Eugenio d'Ors, Carlos Vaz Ferreira, José Ferrater Mora, etc.

Also, from the American side there is a growing number of voices calling for a deeper understanding of the real impact of Hispanic thought in American philosophy. Let us recall the late Peter Hare:

We need to look closely at the relations between the Hispanic world and the American tradition. This need is urgent for many reasons. Hispanic civilization, after all, has been present in this part of the world longer than we conventionally consider European civilization. Only the Native American population has been here longer. American intellectual historians have given little attention to the influence, direct and indirect, that early Hispanic civilization had on the development of American thought. But more important is the demographic reason that soon the Hispanic population will be the largest minority in America. ${ }^{2}$

In this wide framework, the aim of this paper is to describe this situation of mutual ignorance between both traditions, paying special attention to the figure and thought of the founder of pragmatism, Charles S. Peirce (1839-1914). In order to do this, first of all I will justify the usage of the expression "Hispanic Philosophy", highlighting its heuristic and practical value. Secondly, I will discuss some of Peirce's comments in relation with the Hispanic world. And finally, by way of conclusion, I will mention some of the connections that lie nearly hidden under the cloak of ignorance which divides the two traditions.

\section{The notion of Hispanic philosophy}

The term "Hispanic philosophy" used for the philosophical tradition of Spain

\footnotetext{
$1 \quad$ An earlier and briefer version of this presentation was published with the title "C. S. Peirce and the Hispanic Philosophy of the Twentieth Century" in Transactions of the Charles S. Peirce Society 24/1, (1998): 31-49. The present text relies particularly upon the new research published in Jaime Nubiola and Fernando Zalamea, Peirce y el mundo hispánico. Lo que C. S. Peirce dijo sobre España y lo que el mundo hispánico ha dicho sobre Peirce (Pamplona: Eunsa, 2006).

Peter H. Hare, "Introduction. American Philosophy and the Hispanic World", Transactions of the Charles S. Peirce Society 24/1, (1998): 30.
} 
and Latin America was coined by the Catalan philosopher in exile, Eduardo $\mathrm{Nicol}^{3}$. It was the Cuban philosopher, Jorge J. E. Gracia, however, who recently presented a full case in favor of this term as a way of gaining a better understanding of all the philosophical thinking that has been developed over the last few hundred years in Spain and Portugal, the Spanish colonies of the New World, and the countries which grew out them ${ }^{4}$. The concept of Hispanic philosophy is particularly accurate, because it brings out the close relationship between philosophers in these geographical areas, and because the other geographical descriptions that have been used (Spanish philosophy, Portuguese philosophy, Catalan philosophy, Latin American philosophy, Hispano-American philosophy and Ibero-American philosophy) do not do justice to, or neglect, the historical reality of the relations between them.

Nevertheless, the use of a category such as this does not imply-as Nicol believed, and with him scores of Hispanic authors in the twentieth century ${ }^{5}$-that there is some special idiosyncratic trait which characterizes all the figures who have devoted their energies to philosophy within the Hispanic world. Instead, this name should serve to highlight the phenomenon of the real historical relationship between the philosophy of the Iberian Peninsula and that of Latin America, which other descriptions tend to neglect. The authors who form part of this tradition share neither language nor race nor nationality, but they have a common history: it is the historical reality that they share which provides the uniting factor and gives them a certain family resemblance ${ }^{6}$.

One of the features of modern Hispanic philosophy is its isolation from the main current of European thought. The process by which late Hispanic ScholasticismDomingo de Soto, Francisco Suárez, Francisco Araújo, and John Poinsot—broke away from Europe was influenced by many different factors. One of its most regrettable consequences was the resulting ignorance in Europe of the rich creative ferment and speculative depth of this tradition with regard to the central problem of the nature of signs and their activity. John Deely has emphasized that it is in these Hispanic philosophers, rather than the modern Cartesian tradition, that we find "the first genuine awakening of semiotic awareness, that is, the first thematic understanding of the difference between using signs and comprehending their basis, and the ubiquitousness and naturalness of a phenomenon such as semiosis"7.

\section{Peirce's connections with the Hispanic world}

A good indication of the almost complete absence of the Hispanic world from Peirce's cultural horizons is that the only direct mention of Spain in the eight volumes of

\footnotetext{
3 See Eduardo Nicol, El problema de la filosofía hispánica (Madrid: Tecnos, 1961).

4 Jorge J. E. Gracia, "Hispanic Philosophy: Its Beginning and Golden Age", Review of Metaphysics 46 (1993): 475-502.

See Jorge J. E. Gracia and Iván Jaksic (eds.), Filosofía e identidad cultural en América Latina (Caracas: Monte Ávila, 1983); Marcelo Dascal (ed.), Cultural Relativism and Philosophy. North and Latin American Perspectives (Leiden: Brill, 1991), pp. 3-6.

$6 \quad$ Gracia, "Hispanic Philosophy", p. 482.

7 John Deely, "Vindicación de la filosofía hispana: La semiótica como restauración de la cultura intelectual ibérica", Revista de Filosofía 27 (1994): 319; see also Mauricio Beuchot, "La filosofía escolástica en los orígenes de la semiótica de Peirce", Analogía 2 (1991): 155-166. Of particular interest in this context are the efforts made in recent years by Deely, Beuchot and others to identify the links between this late Scholastic philosophy and the vigorously anti-Cartesian thought of the founder of pragmatism, Charles S. Peirce, and his followers.
} 
his Collected Papers is his usage of the English expression, of French origin, "to build castles in Spain", which occurs in his article "A Neglected Argument for the Reality of God", where Peirce explains the notion of "Musement". This term indicates free, unrestrained speculation, in which the mind entertains itself to no particular end, purely playing with ideas: "The particular occupation I mean (...) may take either the form of aesthetic contemplation, or that of distant castle-building (whether in Spain or within one's own moral training) ..." $(C P, 6.458,1908)^{8}$. Nevertheless, Peirce visited Spain briefly in 1870 , and the circumstances of that journey bear witness to the wide scope of Peirce's interests.

In 1861, when finishing his studies in the Lawrence Scientific School at Harvard, Peirce started to work as an aide to his father, Benjamin, in the U. S. Coast Survey. In 1869 Charles S. Peirce was a member of one of the teams in Kentucky studying the total eclipse of the sun on August 7 th. The observation of the solar corona and its protuberances through telescopes, and the detection of helium by use of the spectroscope, led the American astronomers to formulate new theories on the composition of the sun that were received with a certain skepticism by European astronomers. Since no other occasion as favorable was going to arise in the nineteenth century, Benjamin Peirce, the third Superintendent of the Coast Survey, obtained an appropriation from Congress to organize an expedition to observe the next solar eclipse, which was to take place at midday on 22 December 1870 over the Mediterranean Sea. To ensure the success of the project and also to help Charles's international profile as a scientist, Benjamin sent his son to organize the preparations in Europe six months beforehand. Charles had to make adequate arrangements for two teams of observers, and was asked by his father to establish links with such eminent European scientists as Augustus de Morgan, Stanley Jevons and others. As he would write more than thirty years later, Philosophy is a study which needs a very protracted concentrated study before one, so
much as, begins to be at all expert in the handling of it, if one is to be precise,
systematic, and scientific. I gave ten years to it before I ventured to offer half a dozen
brief contributions of my own. Three years later, when I had produced something more
elaborated, I went abroad and in England, Germany, Italy, Spain, learned from their
own mouths what certain students at once of science and of philosophy were turning in
their minds.

Charles passed through London, Rotterdam, Berlin, Dresden, Prague, Vienna and Pest, arriving finally in Constantinople. From Constantinople Peirce went back along the entire path of the eclipse from East to West in search of suitable locations for observatories. Peirce visited Greece and Italy, where he selected some sites in Sicily, and on 28 October Peirce left Florence to begin what he called his "Spanish hurryskurry"10.

\footnotetext{
$8 \quad$ References to Peirce's works are as follows: $C P$ refers to Collected Papers of Charles Sanders Peirce, vols. 1-8, ed. C. Hartshorne, P. Weiss and A. W. Burks, (Cambridge, Mass: Harvard University Press, 1931-58); MS refers to The Charles S. Peirce Papers, 32 reels of the manuscripts housed in the Houghton Library (Cambridge, Mass: Harvard University Library, Photographic Service); $C N$ refers to Contributions to 'The Nation', vols. 1-4, ed. K. L. Ketner and J. E. Cook (Lubbock: Texas Tech Press, 1975-79); and $W$ refers to Writings of Charles S. Peirce: A Chronological Edition, vols. 1-5, ed. M. H. Fisch et al, (Bloomington: Indiana University Press, 1982-95).

9 C. S. Peirce, "Letter to The Sun", MS 325, p. 4, c. 1907.

10 C. S. Peirce, Letter to Sarah Mills Peirce, 16 November 1870; L 341 according to the Annotated Catalogue of the Papers of Charles S. Peirce, by Richard S. Robin (Amherst, Mass: University of Massachusetts Press, 1967).
} 
The highlights of his Spanish trip were probably Malaga, Granada and Madrid. Peirce arrived in the South of Spain by boat in the first days of November. From Málaga, Charles Peirce wrote to his father Benjamin giving him news of his visit and suggesting a possible site in Marbella ${ }^{11}$. In Granada, he was greatly impressed by the Alhambra, which he visited on 7 November; in his Cambridge Conferences Lectures of 1898 , almost thirty years later, he was to compare mathematical hypotheses with the Alhambra decorations: mathematical hypotheses are inferior, but similar: they are "as pretty but soulless"'12. On 12 November 1870 Peirce was in Madrid, as can be seen from the passport he was issued at the United States' legation. Peirce's visit to Spain was extremely brief, less than two weeks. In any case, Peirce did not know Spanish, and he was little more expert after his visit, as he explains in a letter to his mother from Grenoble on the $16^{\text {th }}$ of November: "The Spanish speak as if they had pebbles in their mouths, which makes it very difficult to catch the distinction of their sounds"13.

In fact, Charles S. Peirce joined the group of American scientists, his wife Zina and his father Benjamin among them, who followed the eclipse in the vicinity of Catania (Sicily), even though his spectroscope was sent by mistake to Jerez, Spain, where the second group from the U. S. Coast Survey was finally stationed ${ }^{14}$. Even though the day turned out to be cloudy, with some rain, the observations made by both expeditions on 22 December were successful, and confirmed the conclusions drawn by the Americans on the basis of the previous eclipse. As Joseph Brent wrote, "this expedition was Charles's first experience of large-scale international scientific cooperation, and it illustrated for him the importance of the community of science in reevaluating and validating its hypotheses"15.

Germany, United Kingdom, France and, perhaps to a lesser extent, Italy are the European countries which are mentioned most frequently in Peirce's writings. References to Spain or other countries of the Hispanic world are scarce and on most occasions of a negative tone, in keeping with the insignificant role which these countries played in the scientific and cultural community of Europe during the last quarter of the nineteenth century ${ }^{16}$. My guess is that the real influence of Juliette, his French second wife whom he married in 1883, should not be underestimated ${ }^{17}$.

That letter is lost, but in the Harvard Archives there is a telegram and the response letter of November 16, 1870, from Benjamin Peirce, who was then in Munich, to Joseph Winlock, Director of Harvard Observatory, informing him about Charles's visit (UA V 630.12 Observatory Letters Received 1870-75, $\mathrm{n}^{\circ}$ 48).

12 Charles S. Peirce, Reasoning and the Logic of Things. The Cambridge Conferences Lectures of 1898, ed. K. L. Ketner, (Cambridge, Mass: Harvard University Press, 1992), p. 284, n. 6; and MS 442.

13 In Peirce's letter of November 16 ( $L 341)$, he writes to his mother about how much he admired a statue of a half-reclining woman he saw in Madrid by an artist then living (probably The Nymph Eurydice by Sabino de Medina): "... is one of the most beautiful things I have seen". In that letter Peirce also describes the three purchases he made in Spain: a blanket with gypsy embroidery to keep him warm on his railway journey, an old mother-of-pearl fan, and a dozen photographs of the best paintings he had seen.

14 This latter group, directed by Professor Winlock, then head of Harvard Observatory, was made up of eleven Americans, two Englishmen, and a Spanish observer who joined them. They worked in collaboration with Captain Cecilio Pujazón, director of the Observatorio de San Fernando (Cádiz). The main site chosen was in an olive grove, a mile to the northeast of Jerez, near Seville. See F. J. González González, El Observatorio de San Fernando, 1831-1924 (Madrid: Ministerio de Defensa, 1992), p. 246.

15 Joseph Brent, Charles S. Peirce. A Life (Bloomington: Indiana University Press, 1993), p. 80.

16 "Englishmen are generally so naively ignorant of what takes place in the great world of science (which does not centre in London, as they seem to imagine) that it is possible for a respectable man to publish a book there the existence of which depends on such ignorance as would disgrace him in Sicily or Spain" (CN 1: 47, 1872). 17

Joseph Brent, Charles S. Peirce. A Life, p. 99. 
The only Spaniard with whom Peirce corresponded was Ventura Reyes y Prósper (1863-1922). Reyes was a Spanish mathematician and professor of mathematics in Toledo who corresponded widely with the most well-known mathematicians of his time, whose works he wished to publicize in $\operatorname{Spain}^{18}$. Another Spaniard with whom Peirce had a close relationship was General Carlos Ibáñez de Ibero (1825-91), who lived in Paris and was the cofounder in 1866 and later president (until his death) of the International Geodesic Association ${ }^{19}$.

Peirce himself wrote two letters in The Nation, December 1884, discussing the "Reciprocity Treaty" signed by the United States and Spain in February of that year to regulate the importation of Cuban and Puerto Rican sugar ( $C N$ 1: 65-67, $W$ 5: 144-148). As is well known, the situation was to lead to war between the United States and Spain: "our difficulty with Spain by the destruction of the Maine", as he described it in 1902 (CN 3: 68). When the war finally came about, Peirce wrote to his first cousin, the influential Senator of Massachusetts, Henry Cabot Lodge, offering his contribution to the war effort, in the form of a machine he had invented to code and decode messages, and voicing his prediction that the Spanish would put up little resistance in the war. This letter deserves to be quoted at length:

\section{My dear Cabot}

I take the liberty of reminding you of my strong desire to serve the country in some way at this time, and also to say more explicitly than I did that other things being equal I believe I should be particularly useful were unflurried nerves desirable in a situation of extreme danger. At the same time, I would not decline any position in which I should be of use.

I have from boyhood been taught by all our Massachusetts statesmen the U. S. ought to possess Cuba. I am sorry to say I don't believe the Spaniards will make a good fight; for as I have studied them in Spain, the whole people has been corrupted with the centuries of cruelty, injustice and rapine they have indulged in, and they have little manhood left. (...). ${ }^{20}$

Without any doubt, Charles Peirce was a son of the New England culture of his time, and the letter reflects well the great distance between the Hispanic world and the American culture in those times. In a similar vein, one may read Peirce's letter to his brother Jem:

I am entirely in favor of the war. Two years ago I thought the United States instead of recognizing Cuba, for which there was no justification, ought to have intervened in the name of civilization. Besides, I have always thought we wanted Cuba, and what I have seen of the Cubans makes me think them very superior to the Spaniards of Spain who

\footnotetext{
18

Jesús Cobo, Ventura Reyes Prósper (Badajoz: Departamento de Publicaciones Diputación Provincial de Badajoz, 1991); Jesús Cobo and Jaime Nubiola, "The Spanish Mathematician Ventura Reyes Prósper and his connections with Charles S. Peirce and Christine Ladd-Franklin", Arisbe: The Peirce Gateway, 2000, $<$ http://www.cspeirce.com/menu/library/aboutcsp/nubiola/reyes.htm>

Charles S. Peirce, Historical Perspectives on Peirce's Logic of Science: A History of Science, C. Eisele, ed. (Berlin: Mouton, 1985), pp. 27 and 597; Charles S. Peirce, The New Elements of Mathematics, C. Eisele, ed. (The Hague: Mouton, 1976), vol. 3, pp. 207 and 1135. See J. M. López de Azcona, "Ibáñez e Ibáñez de Ibero, Carlos", in C. G. Gillispie, ed., Dictionary of Scientific Biography (Scribner's: New York, 1981), vol. 7, pp. 1-2.

Peirce letter to Henry Cabot Lodge, 1898?, L 254.
} 
have been thoroughly corrupted by centuries of indulgence in cruelty, injustice, treachery, and rapine. That Cuba will fall into our hands ultimately I have no doubt. Besides, I think on the whole it is clear the Spaniards blew up the Maine, and we ought not to let that pass simply because we cannot produce a formal proof of the fact. We did right in not making it a formal casus belli but still in going to war because of it. Besides that, I think it is a very fortunate thing to have a war with Spain; for we could not go on forever without a war. It might have been Germany, with which we must probably fight sooner or later; certainly we must if we are not prepared for it. Now nothing would ever wake us up but an actual war. ${ }^{21}$

The contemporary reader will be surprised by Peirce's clarity of mind about the unavoidability of a future war with Germany, which became a reality fifteen years later. In any case, both letters reflect well the deep hostility from the American side towards the Hispanic world.

On this vein, I want to take advantage of this session to reply to the review that Daniel G. Campos published a few months ago of the book Peirce and the Hispanic World, co-authored with Fernando Zalamea. Campos praises our patient work of collecting all the available evidences, but he considers that my text "fails to criticize Peirce thoroughly, on the grounds of Peirce's own philosophy, when the distinguished New Englander displays his cultural prejudices in commenting on Hispanic character and culture" ${ }^{22}$. Since Peirce's philosophy might be understood as a conscientious effort of articulating theory and practice, thought and life, "Nubiola's unwillingness to criticize openly and thoroughly Peirce's cultural prejudices against Hispanics [...] strikes me as a major weakness in his study. Peirce fails to live his philosophy in this regard", and he claims that I let Peirce's prejudiced views go "without any indication of possible criticism in terms of his own philosophy" ${ }^{\prime 2}$. Campos takes pains in reproducing in his review several of the anti-Hispanic texts of Peirce, suggesting finally that

Following Trout ${ }^{24}$, then, Peirce's prejudices against Hispanics can be understood as affective habits internalized from his socio-cultural context. He lets these views operate as practical guides for action while failing to identify, criticize, and modify these habits, in spite of his philosophy. There is no suggestion in Nubiola's text, however, that Peirce's unchecked prejudices are indeed a failure to live his philosophy. ${ }^{25}$

How to answer Campos' criticism? It is not easy to answer since his charge could be anachronically extended also to Peirce's occasional sexist and racist expressions or his opposition to the abolition of slavery. My only defense will be a quotation from a letter that Wittgenstein wrote to Ficker about his Tractatus which came to my memory when, while writing my book, I was puzzled about how to treat Peirce's anti-Hispanic prejudices:

My work consists of two parts: the one presented here plus all that I have not written.

\footnotetext{
$21 \quad$ Peirce letter to James Mills Peirce, 7 May 1898, L 339.

22 D. G. Campos, "Review of J. Nubiola and F. Zalamea: Peirce y el mundo hispánico: Lo que C. S. Peirce dijo sobre España y lo que el mundo hispánico ha dicho sobre Peirce", Transactions of the Charles S. Peirce Society 43 (2007), 796.

23 D. G. Campos, "Review of J. Nubiola and F. Zalamea: Peirce y el mundo hispánico", 797 and 798.

24 L. Trout, Communal Inquiry in Social Justice: A Study of Peircean Affectivity, Ph. D. Diss., Pennsylvania State University, 2005.

25 D. G. Campos, "Review of J. Nubiola and F. Zalamea", 799.
} 
And it is precisely this second part that is the important one. [...] I believe that where many others today are just gassing, I have managed in my book to put everything firmly into place by being silent about it ${ }^{26}$.

I did not criticize Peirce's prejudices for a similar reason. The striking point to me is that passing silently over those obvious prejudices is just the European style, while Campos epitomizes the American style of candid explicitness with his reproach to me for not having criticized Peirce in terms of his own philosophy. European elegance is totally opposite to the open American style. Perhaps my comment tonight is an attempt to find a middle way.

Also, I want to add that the anti-Hispanic trend in the American culture has its counterpart in the anti-Americanism that has been a dominant and leading factor-and which is still active today - in Hispanic culture throughout the twentieth century, both in Spain and in the Hispanic countries of Central and South America.

\section{Some connections hidden beneath a mutual incomprehension}

As Vericat suggested, Peirce's reception in Spain has been somewhat shadowy, in the sense that his importance is openly acknowledged, but little is known about what he actually wrote ${ }^{27}$. Much the same could be said of Latin America. However, there is evidence that this is beginning to change: translations are now appearing which make a relevant amount of Peirce's vast production accessible, and in 1994 a "Grupo de Estudios Peirceanos" was founded in Navarra to coordinate and encourage the efforts of researchers from Spain and several Latin American countries; other similar initiatives are appearing in Argentina, Brazil, Colombia and other places. In the last decade a broad interest in Peirce seems to have awakened in most Spanish-speaking countries. There has been a flourishing of careful translations of Peirce, most of them published on the web under the general supervision of Sara Barrena (http://www.unav.es/gep/Peirceesp.html), that make thousands of pages of Peirce's writings available to a wide audience, along with articles about Peirce and pragmatism.

Hispanic philosophy's ignorance of Peirce and of pragmatism in general, and the American pragmatist tradition's lack of knowledge of Hispanic philosophy, are probably the result of mutual cultural incomprehension in which the sociological factors which have separated these two spheres throughout the twentieth century have prevented both parties from recognizing their special affinity. It has often been said that the central problem of Hispanic philosophy in the twentieth century has been that of the connection between thought and life. In very general terms this is also the central theme of American pragmatism. Or rather, pragmatism is a response from scientific and life experience to the typical problem of modern Cartesianism concerning the rift between rational thought and creative vitality. The Hispanic philosophers Unamuno, Ortega and d'Ors, in a way analogous to that of the Italians Papini, Vailati and Calderoni ${ }^{28}$, were

\footnotetext{
26 Wittgenstein letter to Ficker, undated, probably September-October 1919: B. M. McGuinness (ed.), Letters from Ludwig Wittgenstein (Oxford: Blackwell, 1967), p. 143.

27 José Vericat, "Introducción", in C. S. Peirce, El hombre, un signo: (El pragmatismo de Peirce) (Barcelona: Crítica, 1988), p. 15.

28 William James, "G. Papini and the Pragmatist Movement in Italy", Journal of Philosophy 3 (1906), pp. 337-341. For a recent general review, see Giovanni Maddalena and Giovanni Tuzet (eds.), I pragmatisti italiani tra alleati e nemici (Milano: Albo Versorio, 2007).
} 
answering this common problem in a way that was strikingly similar to their North American counterparts. Recognition of this 'community' has been very slow, perhaps because of the decline of pragmatism in previous decades, because of the eternal claim to originality which characterizes the Hispanic tradition, and the typical parochialism of the North American tradition. This peculiar affinity between North American thought and the Hispanic world perhaps accounts for the great spread of the Spanish translations of Ralph W. Emerson and William James in the first decades of the $20^{\text {th }}$ century.

In recent years we have been witnessing a resurgence of pragmatist philosophy in Anglo-American culture, which is generating a transformation of analytic philosophy. One of the landmarks in this process has been the rediscovery and deeper understanding of C. S. Peirce. The growing awareness of the connections between the Hispanic and the North American philosophical traditions-formerly regarded as worlds apart - would seem to offer a better perspective for appraising the philosophical output of the past century.

Moreover, a new phenomenon has appeared in the last few years: Hispanic scholars from different countries and backgrounds have started to listen one to another and to talk to each other about Peirce and the philosophers of classical pragmatism. On the American side there is really a growing awareness of the almost total neglect that the Hispanic philosophical tradition has suffered, as the present session bears witness. The study of Peirce's person and thought may be one of the ways to overcome the typical individualistic isolation of the Hispanic philosophers, and also to close the gap between the American and Hispanic philosophical traditions. 